\begin{tabular}{|l|l|l||}
\hline \multicolumn{2}{|c|}{ PublisherInfo } \\
\hline \hline PublisherName & $:$ & BioMed Central \\
\hline \hline PublisherLocation & $:$ & London \\
\hline \hline PublisherImprintName & $:$ & BioMed Central \\
\hline \hline
\end{tabular}

\title{
Saline infusion induces hyperchloremic acidosis
}

\begin{tabular}{|l|l|l||}
\hline \multicolumn{2}{|c||}{ ArticleInfo } \\
\hline \hline ArticleID & $:$ & 4113 \\
\hline \hline ArticleDOI & $:$ & $10.1186 /$ ccf-1999-335 \\
\hline \hline ArticleCitationID & $:$ & 335 \\
\hline \hline ArticleSequenceNumber & $:$ & 50 \\
\hline \hline ArticleCategory & $:$ & Paper Report \\
\hline ArticleFirstPage & $:$ & 1 \\
\hline \hline ArticleLastPage & $:$ & 4 \\
\hline \hline & & RegistrationDate : 1999-5-20 \\
ArticleHistory & $:$ & OnlineDate \\
\hline \hline ArticleCopyright & $:$ & Current Science Ltd1999-5-20 \\
\hline \hline ArticleGrants & $:$ & \\
\hline \hline ArticleContext & $:$ & 130541111 \\
\hline \hline
\end{tabular}




\section{Keywords}

Crystalloid infusion, gynecology, hyperchloremic acidosis, saline infusion

\section{Comments}

This is an important study with a significant finding for anesthetists and intensivists. As the authors state, the major importance may be in recognising the acidosis for what it is and not trying to increase perfusion or fluid loading to correct it. Large volumes of saline were infused in this study $(6000 \mathrm{ml}$ per case of $2 \mathrm{~h}$ duration) but these volumes were appropriate given a blood loss of $900 \mathrm{ml}$ on average. This scenario may become increasingly relevant to UK practice with the recent controversy surrounding colloids and albumin.

\section{Introduction}

Sodium chloride solution contains a non-physiological concentration of chloride ions (154 mmol/l). Infusion of large volumes of this solution could, therefore, theoretically lead to hyperchloremic acidosis. This complication of fluid therapy has been reported in isolated case reports involving extensive surgery and large fluid loads but has not been investigated in the setting of a randomised controlled trial in patients undergoing moderate surgery.

\section{Aims}

To assess the influence of crystalloid infusion on acid base changes.

\section{Methods}

A total of 24 healthy women (American Society of Anesthesiologists grade I or II) scheduled for elective lower abdominal gynecological surgery were studied. The patients were randomised to one of 
two groups to receive either $0.9 \%$ saline or lactated Ringer's solution. General anesthesia was induced using a standardised anesthetic technique, ventilated to maintain normocapnia $\left(\mathrm{PaCO}_{2}=40 \mathrm{mmHg}\right)$ and warming blankets used to maintain constant patient temperature. At the time of surgical incision arterial blood was drawn for baseline measurements of $\mathrm{PaO}_{2}, \mathrm{pH}, \mathrm{PaCO}_{2}, \mathrm{Na}, \mathrm{Cl}$, total protein and lactate using standard methodology. Blood levels of the above were also measured at $30 \mathrm{~min}$ intervals throughout the first $2 \mathrm{~h}$ of surgery as were temperature, urine output and blood loss. Initial infusion rates were set at 30 $\mathrm{ml} / \mathrm{kg} / \mathrm{h}$. Strong ion difference (SID) was calculated as $\mathrm{Na}^{+} \mathrm{K}^{-} \mathrm{Cl}^{-}$lactate for each sample. Plasma weak acid was calculated from the formula total protein $\mathrm{x}$ 2.43. Derived figures for bicarbonate (BicHH) and base excess (BE) were taken from the blood gas analyser. Bicarbonate was also calculated from the Stewart model as SID - protein (BicS). Anion gap was calculated as $\mathrm{Na}^{+} \mathrm{K}^{-} \mathrm{Cl}^{-} \mathrm{BicHH}$.Appropriate statistical tests were used for the data.

\section{Results}

There were no statistically significant differences in the baseline patient characteristics. A mean of $6000 \mathrm{ml}$ of fluid was infused in both groups. Urine output, blood loss and drop in hemoglobin was similar in both groups. $\mathrm{pH}$ decreased and base deficit increased in the saline group but not in the group receiving lactated Ringer's solution. In the saline group, $\mathrm{pH}$ changed from 7.41 to 7.28 and $\mathrm{BE}$ from -0.4 to $-6.7 \mathrm{mmol} / \mathrm{l}$ at $120 \mathrm{~min}$. Lactate increased slightly in the group receiving lactated Ringer's from $0.5-2$ $\mathrm{mmol} / \mathrm{l}$. Sodium ion concentration increased in the saline group and decreased in the lactated Ringer's group by statistically significant (but clinically insignificant) amounts (approximately $2 \mathrm{mmol} / \mathrm{l}$ ). Chloride ion concentration increased significantly in the saline group from a mean of 104 to $115 \mathrm{mmol} / \mathrm{l}$. Bicarbonate, calculated by either the Henderson-Hasselbalch or Stewart methods, decreased significantly in the saline group.

\section{Discussion}

The main finding of the study was an impressive acidosis ( $\mathrm{pH}$ decreased from 7.41 to 7.28) and increase in base deficit $(0.4$ to $6.7 \mathrm{mmol} / \mathrm{l})$ during surgery of intermediate severity on patients who were otherwise fit and healthy. Using the Henderson-Hasselbalch analysis of the acid base balance, metabolic acidosis was seen to occur with hyperchloremia the most likely cause. The Stewart approach defines things slightly differently with $\mathrm{PaCO}_{2}$, SID and the sum of all the anionic charges on the weak plasma acids being independent $\mathrm{pH}$ regulating variables, and $\mathrm{pH}$ and $\mathrm{Bic}$ being dependent variables. In this way the profound change in the SID $\left(\mathrm{Na}^{+} \mathrm{K}^{-} \mathrm{Cl}^{-}\right.$lactate) would have been responsible. The authors state that the degree of acidosis found would be well tolerated but may cause problems due to overzealous treatment of presumed hypoperfusion or in addition with opiate-induced respiratory acidosis at the end of the case. 


\section{References}

1. Scheingraber S, Rehm M, Schmisch C, Finsterer U: Rapid saline infusion produces hyperchloremic acidosis in patients undergoing gynecological surgery. Anesthesiology. 1999, 90: 1265-1270.

This PDF file was created after publication. 